\title{
PENDAMPINGAN DAN SOSIALISASI SITUS BELAJAR SEBAGAI PENUNJANG PEMBELAJARAN ONLINE
}

\author{
Nurul Fatehah \& Teddy Dyatmika \\ IAIN Pekalongan, Indonesia \\ IAIN Pekalongan, Indonesia \\ teddy.dyatmika@iainpekalongan.ac.id
}

Abstract : The COVID-19 pandemic has had a profound impact on all areas of life, including education. The education system, which was originally face-to-face, had to be replaced with online learning. Various problems arise related to the implementation of the Distance Learning or PJJ system. This system makes parents have to participate more in supervising as well as being a substitute for teachers at home in the learning process of their children. In addition, homeschooling also raises problems where students find it difficult to understand the material given by the teacher. The decrease in enthusiasm for learning becomes a problem when the PJJ system seems monotonous and boring. To support the government's program in breaking the chain of the spread of COVID-19 without reducing the effectiveness of online learning implemented by the Ministry of Education and Culture, this activity was carried out. This activity is expected to help reduce the anxiety of parents who are afraid that their children are not serious and have difficulty in learning. In addition, it is hoped that this activity will help participants to easily understand the material that has not been mastered. The methods of socialization, demonstration, and mentoring are carried out directly. The success of this activity can be seen from the assistance of the participants in solving the problems faced and the enthusiasm of the

Nurul Fatehah \&

Teddy Dyatmika| 149

gurnal Pengabdian Masyarakat 
participants during the activity.

Keywords: covid-19, learning assistance, online learning

\section{Pendahuluan}

Pada tanggal 30 Januari 2020 World Health Organization (WHO) menetapkan adanya keadaan darurat kesehatan masyarakat yang meresahkan dunia atau Public Health Emergency of International Concern (KKMMD/PHEIC). Dilansir dari situs Kompas.com, Presiden Jokowi lewat penerbitan Keputusan Presiden Nomor 12 Tahun 2020 tentang Penetapan Bencana Non alam Penyebaran Corona Virus Disease 2019 (Covid-19) sebagai bencana nasional pandemi covid-19 1. Adanya keputusan tersebut menjadikan pemerintah membentuk Gugus Tugas Percepatan Penanganan Covid-19. Berbagai upaya dilakukan untuk menanggulangi dan memutus rantai penyebaran Covid-19, mulai dari Pembatasan Sosial Berskala Besar (PSBB) hingga Pemberlakuan Pembatasan Kegiatan Masyarakat (PPKM) baik itu mikro maupun makro. Hal ini sangat mempengaruhi kehidupan manusia dalam berbagai bidang. Khususnya pada bidang pendidikan. Sejak diterbitkannya Surat Edaran Nomor 15 Tahun 2020 tentang Pedoman

\footnotetext{
${ }^{1}$ Ihsanuddin, "Presiden Jokowi Teken Keppres Tetapkan Wabah Covid-19 Bencana Nasional," Kompas, last modified 2020, https://nasional.kompas.com/read/2020/04/13/18101841/presiden-jokowi-tekenkeppres-tetapkan-wabah-covid-19-bencana-nasional.

Vol. 3 No.2, Oktober 2021

Nurul Fatehah \&

Teddy Dyatmika| 150 
Penyelenggaraan Belajar Dari Rumah Dalam Masa Darurat Penyebaran Covid-19 oleh Kemendikbud Reublik Indonesia, maka seluruh kegiatan pendidikan dilakukan dengan sistem pembelajaran jarak jauh (PJJ) atau biasa disebut dengan pembelajaran daring atau pembelajaran online. Hal ini bertujuan untuk memastikan pemenuhan hak peserta didik untuk mendapatkan layanan pendidikan selama darurat Covid-19, melindungi warga satuan pendidikan dari pengaruh buruk Covid-19, mencegah penyebaran dan penularan Covid-19, serta sebagai pemenuhan dukungan psikososial bagi pendidik, peserta didik, dan orang tua. Pembelajaran yang sebelumnya dilakukan secara konvensional yaitu tatap muka secara langsung, berubah menjadi pembelajaran daring di rumah masing-masing.

Berlakunya kebijakan PJJ menjadikan para pelaku pendidikan khususnya pelajar harus mampu beradaptasi dengan adanya sistem tersebut. Pelajar memiliki tanggung jawab untuk memaksimalkan pembelajaran dengan memanfaatkan teknologi ataupun media pembelajaran yang ada. Di Desa Bojong Lor, Kecamatan Bojong, Kabupaten Pekalongan, Provinsi Jawa Tengah terdapat 235 penduduknya merupakan pelajar terdiri dari Sekolah Dasar hingga Sekolah Menengah dari beberapa lembaga pendidikan sekitar daerah Bojong. Kondisi pandemi Covid-19 menjadikan para pelajar harus 
melakukan pembelajaran di rumah yang tak jarang menjadikan para orang tua harus ekstra dalam mengawasi kegiatan belajar anaknya. Dimana kebanyakan dari pelajar mengeluhkan kesulitannya dalam beradaptasi dengan pembelajaran yang ada.

Khususnya pada pelajar Desa Bojong Lor baik itu dari RT 001 dan 002 dari situasi yang ada, nampak beberapa pelajar menganggap enteng dan terkesan merasa tidak peduli dengan sistem pembelajaran daring. Mereka justru memandang keadaan ini sebagai peluang mereka untuk tidak perlu datang ke sekolah dari pagi hingga siang, memakai seragam lengkap, dan memperhatikan dengan baik guru yang sedang menjelaskan materi. Pada awal masa pemberlakuan PJJ, masyarakat khususnya pelajar di Desa Bojong Lor menerapkan dengan baik peraturan yang ada dengan tetap melakukan pembelajaran di rumah masing-masing. Namun seiring waktu, masyarakat sudah tidak melakukan protokol kesehatan dengan menjaga jarak. Hal ini menjadikan para pelajar abai dan tetap berkerumun. Sebagian dari mereka lebih memilih membuang waktunya dengan bermain game online bersama temannya atau membuat konten di media sosial yang saat ini sedang trend yaitu TikTok daripada memanfaatkan waktu yang ada dengan memperdalam materi yang sudah diberikan oleh guru.

Permasalahan lain muncul ketika semangat belajar para pelajar 
menurun. Mereka cenderung malas saat diberikan tugas oleh guru, mereka lebih memilih untuk langsung menyelesaikannya dengan mencari jawaban yang ada melalui Google tanpa mengetahui bagaimana cara penyelesaiannya dan langsung menyalin apa yang tersedia di situs tersebut. Bahkan saat pelaksanaan ulangan baik itu ulangan harian atau pun ulangan semester, mereka cenderung tidak belajar dan hanya mengandalkan jawaban yang ada di Google. Kemudahan mereka dalam menemukan jawaban membuat mereka malas untuk belajar dan menyelesaikan soal tersebut sendiri. Ditambah lagi dengan perolehan nilai mereka yang lumayan memuaskan. Sehingga mereka berfikir tidak perlu belajar untuk mendapatkan nilai yang bagus. Hal ini dapat menurunkan semangat belajar mereka dan fungsi otak mereka karena tidak dibiasakan untuk berfikir menyelesaikan soal yang mereka dapatkan.

Berdasarkan beberapa permasalahan yang sudah dipaparkan, solusi yang ditawarkan adalah mengadakan sosialisasi dengan memberikan edukasi atau informasi terkait beberapa media atau situs yang dapat para pelajar akses dalam menunjang pembelajaran online yang dinilai kurang maksimal dalam pemberian materi atau pun kurang jelasnya pemaparan yang dijelaskan oleh guru mereka. Selain itu, ada pula pendampingan belajar dengan membantu para pelajar yang 
kesulitan dalam mengerjakan tugas yang diberikan. Sehingga diharapkan dengan adanya kegiatan ini dapat membantu para pelajar Desa Bojong Lor, RT 001 dan 002 yang kesulitan dalam memahami materi atau pun menyelesaikan tugas yang diberikan selama masa pembelajaran online.

\section{Metode}

Sosialisasi dan pendampingan belajar bagi pelajar di Desa Bojong Lor, RT 001 dan 002, Kecamatan Bojong, Kabupaten Pekalongan sudah dilakukan sejak Mei 2021. Kegiatan ini dikhususkan bagi pelajar Sekolah Menengah Pertama (SMP) dan Sekolah Menengah Atas (SMA). Metode yang digunakan yaitu dengan cara terjun langsung ke lapangan untuk melakukan sosialisasi. Beberapa kegiatan yang dilakukan yaitu:

1. Tahap pertama yaitu pemberian informasi mengenai beberapa situs penunjang pembelajaran, cara pembuatan akun yang akan digunakan untuk mengakses situs, dan penginformasian cara penggunaan media atau situs pembelajaran.

a. Tahap pemberian informasi situs penunjang pembelajaran. Situs yang dimaksud yaitu mejakita.com, dan Rumah Belajar. Kegiatan dilakukan dengan metode sosialisasi.

b. Bagi yang belum memiliki akun atau e-mail, mereka dibantu untuk membuat akun yang akan digunakan untuk mengakses 


\section{ISSN : 2656-5161}

situs pembelajaran. Kegiatan dilaksanakan dengan metode demonstrasi dengan memberikan pengarahan secara langsung.

c. Setelah memiliki akun masing-masing, mereka diarahkan tentang bagaimana cara mengakses dan penggunaan situs. Kegiatan dilakukan dengan metode sosialisasi dan demonstrasi yang langsung diikuti oleh peserta dengan membawa handphone masing-masing.

2. Tahap pendidikan berkelanjutan yaitu pendampingan belajar meliputi kegiatan membantu para pelajar yang kesulitan dalam memahami materi, menyelesaikan tugas, ataupun masalah yang dialami ketika mengalami kesulitan atau kurang memahami situs pembelajaran yang sudah disosialisasikan. Kegiatan ini dilakukan secara fleksibel dengan memanfaatkan media whatsapp. Mereka yang membutuhkan bantuan dapat menghubungi lewat pesan chat maupun secara langsung datang ke tempat sosialisasi pembelajaran.

\section{Hasil dan Diskusi}

Adanya Covid-19 mendesak berbagai elemen dalam dunia pendidikan beradaptasi dengan situasi yang ada. Slogan work from home dan study from home begitu familiar saat ini. hal ini tentunya berdampak besar bai berbagai pihak dalam dunia pendidikan. Secara umum, selama ini sistem pendidikan di Indonesia dilakukan secara 
langsung dalam ruang kelas (on-site) dengan bertatap muka. Namun, sejak adanya pandemi, sistem ini berubah menjadi pembelajaran daring atau online melalui berbagai media penunjang seperti handphone atau laptop.

Berbagai pihak yang ada dalam bidang pendidikan harus berupaya untuk dapat memaksimalkan proses pembelajaran jarak jauh agar tidak terjadi kelumpuhan dalam bidang pendidikan. Kondisi ini mendorong semua pihak supaya dapat memahami sekaligus mempraktikan sistem pembelajaran daring yang sebelumnya cukup asing bagi khalayak.

a. Pembelajaran Daring

Kegiatan pembelajaran sejatinya dilakukan melalui interaksi antara pengajar dengan peserta didik dalam suasana lingkungan belajar 2. Pembelajaran bermakna sebagai suatu proses pencerahan yang dilakukan guru untuk membantu siswa mendapatkan pembelajaran dan mampu memahami materi pembelajaran yang diberikan ${ }^{3}$. Pembelajaran daring disebut sebagai sebuah inovasi pendidikan yang melibatkan unsur teknologi informasi dalam pembelajaran ${ }^{4}$.

2 Meda Yuliani, Janner Simarmata, and Siti Saodah, Pembelajaran Daring Untuk Pendidikan: Teori Dan Penerapan (Yayasan Kita Menulis, 2020).

3 Abd Rahim Mansyur, "Dampak COVID-19 Terhadap Dinamika Pembelajaran Di Indonesia," Education and Learning Journal 1, no. 2 (2020): 113.

4 Yani Fitriyani, Irfan Fauzi, and Mia Zultrianti Sari, "Motivasi Belajar Mahasiswa

Nurul Fatehah \&

Teddy Dyatmika| 156

gurnal Pengabdian Masyarakat 
Pembelajaran daring adalah pembelajaran yang menggunakan jaringan internet dengan aksesibilitas, konektivitas, fleksibilitas, dan kemampuan untuk memunculkan berbagai jenis interaksi pembelajaran. Pembelajaran daring pertama kali diperkenalkan oleh Universitas Illionis dengan menerapkan perkembangan pembelajaran berbasis elektronik (e-learning). E-learning memfasilitasi siswa untuk dapat belajar dimana saja dan kapan saja tanpa batasan jarak. Media pembelajaran digunakan lebih bervariasi tidak terbatas pada media verbal, tetapi juga mencakup visual, audio, dan gerak. Pembelajaran daring ditunjang dengan berbagai teknologi informasi yang dapat dimanfaatkan sebagai media pembelajaran, seperti:

1. Google Classroom adalah aplikasi ruang kelas yang disediakan oleh Google.

2. Zoom merupakan aplikasi yang digunakan untuk pembelajaran virtual. Melalui aplikasi Zoom peserta didik dan pengajar dapat bertatap muka secara virtual.

3. Youtube, aplikasi ini digunakan sebagai media untuk memberikan materi berupa video pembelajaran dari pengajar yang dapt diakses oleh peserta didik.

Dalam proses pembelajaran daring, kelebihan yang bisa didapat

Pada Pembelajaran Daring Selama Pandemik Covid-19," Profesi Pendidikan Dasar 7, no. 1 (2020): 121-132.

Vol. 3 No.2, Oktober 2021

Nurul Fatehah \&

Teddy Dyatmika| 157

gurnal Pengabdian Masyarakat 
yaitu pembelajaan bersifat mandiri dan interaktivitas tinggi, dapat dilakukan kapan saja dan dimana saja, hemat biaya, dan menambah pengetahuan di bidang Teknologi Informasi. Selain memiliki kelebihan, tentu saja pembelajaran daring memiliki banyak kekurangan yaitu: timbulnya masalah kesehatan seperti mati rasa karena duduk terlalu lama di depan komputer dan adanya gangguan mata karena terlalu sering menatap layar handphone, laptop atau komputer. Selain itu adanya hambatan gangguan sinyal cenderung lebih berpangaruh pada proses pembelajaran daring. Hal ini dapat mempengaruhi tingkat pemahaman peserta didik terhadap materi yang diberikan oleh pengajar.

Di Desa Bojong Lor khususnya dari RT 001 dan 002, banyak pelajar yang memanfaatkan wifi pada saat proses pembelajaran. Mereka biasanya berkumpul di salah satu rumah warga yang menyediakan layanan wifi dengan tarif Rp.2000,- untuk satu hari. Dari hasil observasi pada saat mereka melakukan proses pembelajaran daring, sebagian terlihat tidak serius mendengarkan penjelasan dari guru. Selain itu dalam beberapa kesempatan, pada saat ulangan, mayoritas dari mereka hanya mengandalkan jawaban dari Google tanpa mencari tahu sendiri jawabannya. Hal tersebut membuktikan bahwa pembelajaran daring kurang efektif ditambah tidak adanya pengawasan dari orang tua 
menjadikan semangat belajar mereka turun.

b. Situs atau Aplikasi Penunjang Pembelajaran

Proses pembelajaran daring memiliki kekurangan yaitu hambatan sinyal internet. Hal ini menjadikan peserta didik kurag memahami materi yang diberikan pengajar. Proses pembelajaran yang terkesan singkat, juga menjadi hambatan bagi pengajar untuk dapat menjelaskan secara rinci topik yang dibahas. Oleh karena itu, pemerintah atau Kemendikbud telah bekerjasama dengan beberapa situs sebagai bahan atau media tambahan pembelajaran yang dapat diakses oleh peserta didik secara gratis. Beberapa diantaranya yaitu:

1. Rumah Belajar

2. Meja Kita

3. Ruang Guru

4. Quipper

5. Zenius

Pada saat proses sosialisasi yang diikuti peserta yang bersekolah di SMAN 1 Bojong dan bersekolah di SMP N 1 Bojong. Pada awal kegiatan sosialisasi pengenalan beberapa aplikasi tambahan untuk belajar, peserta mengakui bahwa mereka hanya mengenal beberapa aplikasi yang sudah disebutkan di atas seperti Ruang Guru, Quipper, dan Zenius. Tetapi masalah yaang muncul adalah adanya beberapa fitur 
dalam aplikasi tersebut yang hanya bisa diakses bagi pengguna yang sudah berlangganan. Hal ini menjadikan adanya keterbatasan bagi pengguna non premium. Hanya 2 peserta yang memiliki akses sebagai pengguna premium yaiyu ruang guru dan quipper sehingga sisanya tidak memiliki akses yang lebih luas untuk mendapatkan semua fitur yang ada pada aplikasi. Keterbatasan biaya menjadi hal utama bagi orang tua sehingga tidak bisa membiayai anaknya untuk mendapatkan program belajar tambahan di luar kegiatan di sekolah. Tahap sosialisasi pengenalan situs pembelajaran daring selanjutnya yaitu menjelaskan bagaimana cara penggunaan fitur-fitur dari situs Meja Kita dan Rumah Belajar. Peserta sosialisasi dituntun secara langsung untuk bagaimana cara memanfaatkan situs tersebut. Dimulai dari situs Rumah Belajar, peserta sosialisasi diberikan penjelasan terkait fitur yang terdapat dalam situs tersebut, meliputi:

1. Kelas digital berisi materi pelajaran yang sudah di upload oleh pengajar dari berbagai daerah di Indonesia yang dapat diakses secara gratis oleh peserta didik. Pelajar dapat mencari terkait topik apa saja yang dibutuhkan. Materi sudah dibagi berdasarkan tingkat pendidikan baik itu SD, SMP, SMA atau SMK. Bahkan dalam situs ini terdapat fitur untuk tingkat pendidikan PAUD, SLB, ataupun 
paket. Materi disajikan dalam berbagai bentuk menarik berupa gambar, video, animasi atau bahkan pemainan.

2. Bank soal berisi kumpulan soal atau evaluasi yang beguna untuk menguji pelajar terkait materi yang ada.

Tahap selanjutnya yaitu pengenalan situs Meja Kita. Dibandingkan dengan Rumah Belajar, situs ini memiliki fitur yang lebih banyak dan bervariasi. Fitur yang terdapat dalam situs Meja Kita yaitu:

1) Materi Belajar berisi materi yang dibutuhkan pelajar. Materi disesuaikan tingkat pendidikan yaitu SD, SMP, dan SMA/SMK mulai dari Matematika, Bahasa Indonesia, Biologi, Kimia, Fisika, Bahasa Inggris, dan lain sebagainya.

2) Latihan Soal berisi soal mulai dari latihan untuk Try Out, UN, bahkan SBMPTN.

3) Diskusi PR berupa halaman untuk pelajar yang memiliki tugas rumah atau PR dapat membagikan PR nya yang kurang dipahami sehingga pelajar lain atau bahkan dari pihak pengajar atau tutor bisa memberikan jawaban disertai cara penyelesaian atau pembahasannya.

4) Berbagi Catatan berupa halaman untuk pengguna yang bersedia atau suka rela membagikan hasil catatannya sendiri untuk dibagikan kepada pengguna lain. 
5) Belajar Bersama berupa fitur yang menyediakan kelas online bagi yang ingin mengadakan seperti webinar untuk membahas suatu topik tertentu.

Dengan diadakannya sosialisasi, peserta kegiatan merasa terbantu untuk mencari materi tambahan dimana mereka merasa jika penjelasan dari guru kurang memuaskan. Selain itu mereka lebih semangat dalam belajar dengan adanya berbagai fitur menarik dari masing-masing situs. Situs tersebut dapat diakses kapan pun dan dimanapun, sehingga saat pelajar lupa terkait topik tertentu dapat mengulang materi yang tersedia. Tahap selanjutnya yaitu pendampingan belajar. Tahap ini dilakukan secara fleksibel, peserta sosialisasi yang merasa masih belum memahami materi yang diberikan guru atau bahkan materi dari situs belajar, datang langsung bertemu. Kegiatan ini berupa penjelasan materi atau membantu peserta yang mendapatkan tugas rumah. Bagi beberapa peserta mengaku bahwa pembelajaran yang dijelaskaan secara langsung lebih mudah dipahami dan diterima dengan baik sehingga mereka mengetahui dan memahami materi yang diberikan. Pendampingan belajar dilakukan untuk membantu menyelesaikan tugas tersebut. 


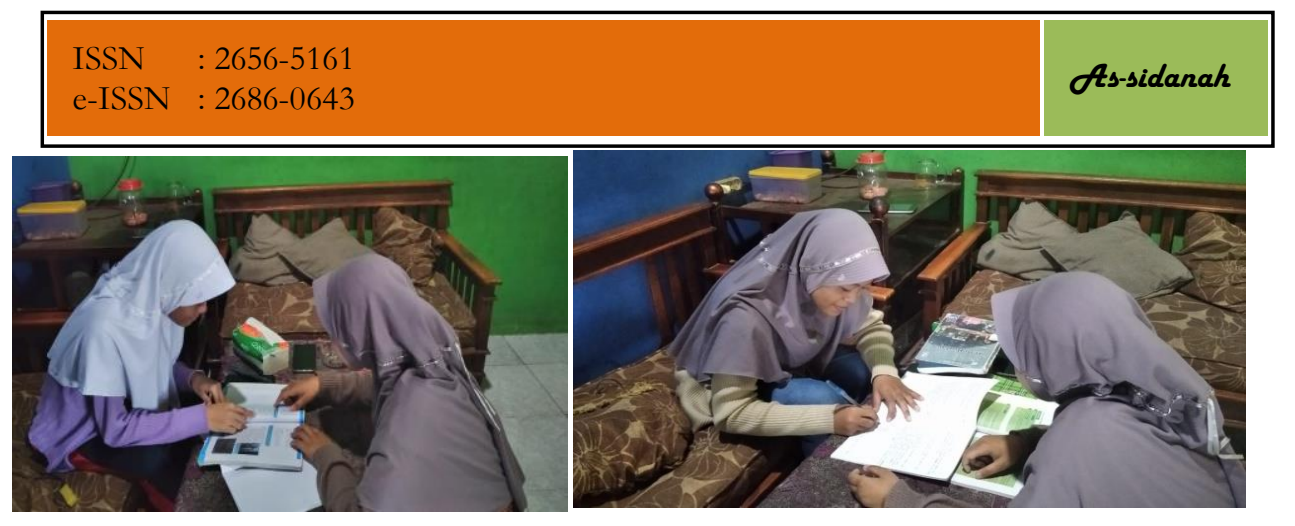

Gambar 1 Kegiatan pendampingan belajar berupa membantu mengerjakan tugas sekolah

Setelah itu, peserta sosialisasi mengusulkan untuk mengadakan belajar bersama untuk mempersiapkan adanya Penilaian Akhir Semester (PAS).

Tabel 1. Tabel Kegiatan

\begin{tabular}{|l|l|l|c|l|}
\hline \multirow{2}{*}{ No } & \multicolumn{1}{|c|}{$\begin{array}{c}\text { Nama } \\
\text { Kegiatan }\end{array}$} & $\begin{array}{c}\text { Waktu } \\
\text { Pelaksanaan }\end{array}$ & Peserta & Hasil Kegiatan \\
\hline 1 & $\begin{array}{l}\text { Sosialisasi dan } \\
\text { demonstrasi }\end{array}$ & & & $\begin{array}{l}\text { Peserta } \\
\text { mengetahui } \\
\text { sekaligus }\end{array}$ \\
& 23 Mei 2021 & 6 & $\begin{array}{l}\text { memahami } \\
\text { beberapa situs } \\
\text { untuk menunjang } \\
\text { pembelajaran } \\
\text { daring dan } \\
\text { mengetahui cara }\end{array}$ \\
\hline
\end{tabular}

Vol. 3 No.2, Oktober 2021

Nurul Fatehah \&

Teddy Dyatmika| 163

Qurnal Pengabdian Masyarakat 


\begin{tabular}{|c|c|c|c|c|}
\hline & & & & menggunakannya. \\
\hline 2 & $\begin{array}{l}\text { Pendampingan } \\
\text { belajar }\end{array}$ & 25 Mei 2021 & 2 & $\begin{array}{l}\text { Peserta dapat } \\
\text { menyelesaikan } \\
\text { tugas yang } \\
\text { diberikan guru } \\
\text { dan memahami } \\
\text { beberapa materi } \\
\text { yang belum } \\
\text { dikuasai. }\end{array}$ \\
\hline 3 & $\begin{array}{l}\text { Pendampingan } \\
\text { belajar }\end{array}$ & 27 Mei 2021 & 2 & $\begin{array}{l}\text { Peserta dapat } \\
\text { memahami materi } \\
\text { yang belum } \\
\text { dikuasai. }\end{array}$ \\
\hline 4 & $\begin{array}{l}\text { Pendampingan } \\
\text { belajar }\end{array}$ & 30 Mei 2021 & 2 & $\begin{array}{l}\text { Peserta dapat } \\
\text { mempersiapkan } \\
\text { dengan baik } \\
\text { materi yang akan } \\
\text { diujikan. }\end{array}$ \\
\hline 5 & $\begin{array}{l}\text { Pendampingan } \\
\text { belajar }\end{array}$ & 31 Mei 2021 & 4 & $\begin{array}{l}\text { Peserta dapat } \\
\text { mempersiapkan } \\
\text { dengan baik } \\
\text { materi yang akan } \\
\text { diujikan. }\end{array}$ \\
\hline
\end{tabular}

Nurul Fatehah \&

Teddy Dyatmika| 164

gurnal Pengabdian Masyarakat 
Dari hasil kegiatan dapat diketahui faktor pendukung kegiatan sosialisasi dan pendampingan belajar yaitu adanya dukungan dari orang tua peserta yang merasa tidak bisa mengawasi dengan baik proses belajar daring anaknya. Mereka juga kewalahan jika anaknya bertanya terkait suatu topik pembelajaran namun tidak bisa membantu untuk menjawabnya. Melihat dari beberapa pelajar yang mengalami kesulitan dalam memahami materi pelajaran dan kurangnya pengawasan dari orang tua yang menjadikan anaknya lebih memilih untuk bermain game maka kegiatan ini dilaksanakan dengan harapan membantu untuk menyelesaikan permasalahaan tersebut.

Beberapa hal yang menjadi faktor penghambat kegiatan yaitu: (1) kurangnya orang untuk membantu kelancaran kegiatan (2) keterbatasan waktu yang harus menyesuaikan kegiatan pendamping yang masih kuliah, (3) kurangnya sarana dan prasana yang lebih memadai.

\section{Kesimpulan}

Program KKN-KK yang dilaksanakan di waroeng kopi singgah di Jalan Raya Pilang no.200, Wonoayu, Sidaorjo berjalan dengan baik dan disambut dengan antusias oleh pemilik. Dalam pelaksanaan program ini dilakukan serangkaian kegiatan yaitu pembuatan Rebrading logo yang diharapakan memberikan suatu kesan yang lebih sederhana dan 
mengubah tipografi pada tulisan waroeng kopi singgah dengan tambahan ikon kopi pada huruf O. Selain itu juga dibuat varian produk kopi singgah dengan tiga jenis varian. Untuk mendukung penjualan dibuatkannya banner dan pemasaran melalui media online seperti facebook, Instagram, dan shopee. Melalui kegiatan yang dilakukan memberikan suatu pengembangan, pengetahuan, meningkatkan omset dengan didorong penjualan dengan media online dan membantu produk waroeng singgah dapat dikenal oleh khalayak umum.

\section{Daftar Pustaka}

Bakhri, Syamsul, Teddy Dyatmika, and M. Rikzam Kamal. "Pengaruh Kemampuan Menggunakan Teknologi Komunikasi, Sosialisasi Media Pembelajaran Online, Dukungan Keluarga Dan Pengajar Terhadap Keaktifan Mahasiswa Di Masa Pandemi Covid-19." MEDIAKITA 4, no. 1. 2020.

Fitriyani, Yani, Irfan Fauzi, and Mia Zultrianti Sari. "Motivasi Belajar

Mahasiswa Pada Pembelajaran Daring Selama Pandemik Covid19." Profesi Pendidikan Dasar 7, no. 1. 2020.

Ihsanuddin. "Presiden Jokowi Teken Keppres Tetapkan Wabah Covid19 Bencana Nasional." Kompas. Last modified 2020. https://nasional.kompas.com/read/2020/04/13/18101841/presidenjokowi-teken-keppres-tetapkan-wabah-covid-19-bencana-nasional. Mansyur, Abd Rahim. "Dampak COVID-19 Terhadap Dinamika Pembelajaran Di Indonesia." Education and Learning Journal 1, no. 2. 2020.

Yuliani, Meda, Janner Simarmata, and Siti Saodah. Pembelajaran Daring Untuk Pendidikan: Teori Dan Penerapan. Yayasan Kita Menulis, 2020. 